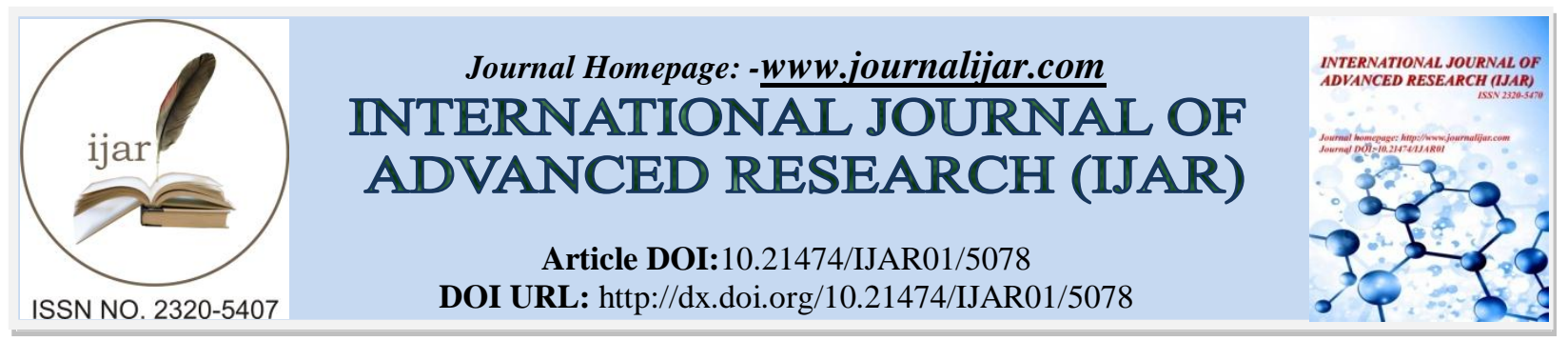

RESEARCH ARTICLE

\title{
PERCEPTIONS AND ATTITUDES OF FILIPINO COLLEGE LEARNERS TOWARD SPANISH AS A FOREIGN LANGUAGE.
}

Noel B. Manarpiis.

Assistant Professor II, Department of Education and ManagementCavite State University-Tanza Campus, Philippines.

\section{Manuscript Info}

Manuscript History

Received: 05 June 2017

Final Accepted: 07 July 2017

Published: August 2017

Keywords:-

language attitude, foreign language study, language perceptions.

\begin{abstract}
The study found out the attitudes of the Filipino learners toward Spanish. Anchored on Gardner and Macintyre's (1993) Socioeducational Model that looks at among others, the students' attitudes toward a foreign language, the study hypothesized that there is no significant difference among the varied perceptions of the students toward Spanish; and, there is no significant difference among the varied attitudes of the students toward Spanish. Descriptive statistics frequency, counts, and percentages and the Analysis of Variance (ANOVA) were used to determine the significant differences among the perceptions and attitudes of students. English was chosen by the participants as the most important language to learn and Spanish as their last choice thinking of these as useful languages when they go abroad to work. They perceived that Spanish is a "difficult" language. Majority thought of it as a "powerful," "productive," and "best" language. Overall result of the study showed that the hypothesis that says there is no significant difference among the varied perceptions of the students toward Spanish is rejected. The alternative hypothesis is thus accepted. This means that the participants had varying degrees of perception towards Spanish. It is suggested that Spanish, though not anymore familiar to the new generation Filipinos, remains a highlyesteemed language. The positive findings reflected the Filipino's interest in learning a new language for the purpose of going abroad. It also indicates their compliance to learning foreign languages as part of their program in college.
\end{abstract}

Copy Right, IJAR, 2017,. All rights reserved.

\section{Introduction:-}

Ryan et al. (1982) defined language attitude as "any effective, cognitive, or behavioral index of evaluative reactions toward different language varieties or speakers." This definition does not entail physical manifestations a person shows but actually refers to the cognitive part or what one thinks or perceives about a language he or she is being confronted with.

The social neuroscientists Petty and Cacioppo (1981) asserted that the word "attitude" should be used to refer to a general or enduring positive or negative feeling about some person, object, or issue. This definition is best applied in

Corresponding Author:-Noel B. Manarpiis.

Address:-Assistant Professor II, Department of Education and ManagementCavite State University-Tanza 452 
the study of language attitudes especially as learners of a new language behave to show whether they accept or reject a particular new language.

In the Philippines, the Filipinos have endured, since time immemorial, the many languages and dialects that they hear every now and then. Being multilinguals, it is not uncommon for a Filipino to listen to somebody speak Tagalog in one area, then Cebuano in another area, and then Hiligaynon, Maranaon, and other Philippine languages all being spoken by various groups of Filipinos all at the same time in just one room or one place. Add to this the second language English which is being spoken by everyone in the community. Indeed, the average Filipino is a multilingual (Ang, 1978) who can speak Tagalog, one's mother tongue, and English. For this reason, it is not a heavy task for a Filipino learner to learn a new language like French, German, or even Spanish.

While there is truth to this statement, the Filipinos also have varying attitudes toward studying a new language. This can be greatly observed inside the tertiary classroom as the language teacher teaches a foreign language like French, German, Spanish, Nihongo, or Spanish. The learners react to a word, a phrase, or even a sentence or a paragraph. Verbal communications or direct remarks like "It's difficult to pronounce!" or "Oh no!" or nonverbal communication or indirect remarks such as laughter, making faces, or scratching one's head - these are manifestations that these learners either accept or reject learning a new language.

Eagly and Chaiken (2005) explained that attitude is "a psychological tendency that is expressed by evaluating a particular entity with some degree of favor or disfavor". They enumerated three kinds of attitude durations: 1) enduring attitude through one's lifetime, 2) formed but then changed attitude, and 3) formed but eventually receding and disappearing attitude.

This study is about the attitudes of young adult Filipinos toward learning Spanish in a tertiary classroom setting. This language can be considered common to old timer Filipinos because of its background in the annals of Philippine history. Spain colonized the entire archipelago for 333 years, yet, the Spanish officials of that period did not allow the Filipinos to learn much about Spanish. Borlongan (2009) explained that in the span of more than 300 years (1565-1898), the conquerors "used Spanish in the controlling domains of language except in the semicontrolling domain of religion." Spanish was used for the evangelization in the country instead of teaching this to the natives. For this reason Borlongan (2009) quoting Sibayan (2000) said that hispanismos emerged out of the priests' learning of the local languages. This is why the conquerors left considerable imprints of their colonization on the Tagalog language of the Filipinos. For this reason, the main Philippine language (Tagalog) and the other Philippine languages and dialects are mixed with Spanish words.

For a while in the Philippines, Borlongan (2009) noted that the Spanish language was the aspired-for language of that time. The government and higher education had no choice but to use Spanish as the language of commerce and trade, which created a distinction between the poor who could only speak their dialects and the very few elites (ilustrados) who are able to acquire Spanish through education in Spanish-run universities in the country or an education in Spain.

Things changed however when the Americans arrived in the Philippines. In contrast to the adamant attitude of the Spanish government toward helping the Filipinos to communicate in Spanish, the American government, on the other hand, pursued with vigor and enthusiasm to teach English to the Filipinos (Sibayan, 2000) in the most benevolent way possible.

Nowadays, the Spanish language is hardly being heard of and is therefore almost foreign to the modern Filipino learners. However, the 1987 Constitution of the Republic of the Philippines clearly states in Article IV Section 7 that "Spanish [and Arabic] shall be promoted on a voluntary and optional basis. With this reason however, Mexican and Spanish-oriented telenovelas (television soaps) that are being aired on Philippine televisions are dubbed in Filipino. The Spanish language is still being offered as a course in college in some programs like Hotel and Restaurant Management, Tourism, Foreign Service, International Studies, etc.

\section{Statement of the Problem:-}

The study found out the attitudes of the Filipino learners towards Spanish. Specifically, the study answered the following:

1. How do the young adult Filipino learners perceive Spanish as a foreign language? 
2. What attitudes do the learners have toward Spanish?

3. What is the academic performance of students in Spanish?

4. Is there a significant difference among the varied perceptions of the students toward Spanish?

5. Is there a significant difference among the varied attitudes of the students toward Spanish?

\section{Objectives of the Study:-}

Generally, the study sought the language attitude of the Filipino learners toward Spanish. Specifically, the study sought to answer the following objectives:

1. Find out how young adult Filipino learners perceive Spanish as a foreign language;

2. Find out what attitudes learners have toward Spanish

3. Find out the academic performance of students in Spanish;

4. find out the significant differences among the varied perceptions of the students toward Spanish; and

5. find out the significant differences among the varied attitudes of the students toward Spanish

\section{Theoretical Framework:-}

This research is generally anchored on the vast studies of sociolinguistics and on the theory of foreign or second language acquisition. Specifically, this research adheres to Gardner and Macintyre's (1993) Socio-educational Model. The theoretical framework of this model is presented in Figure 1.

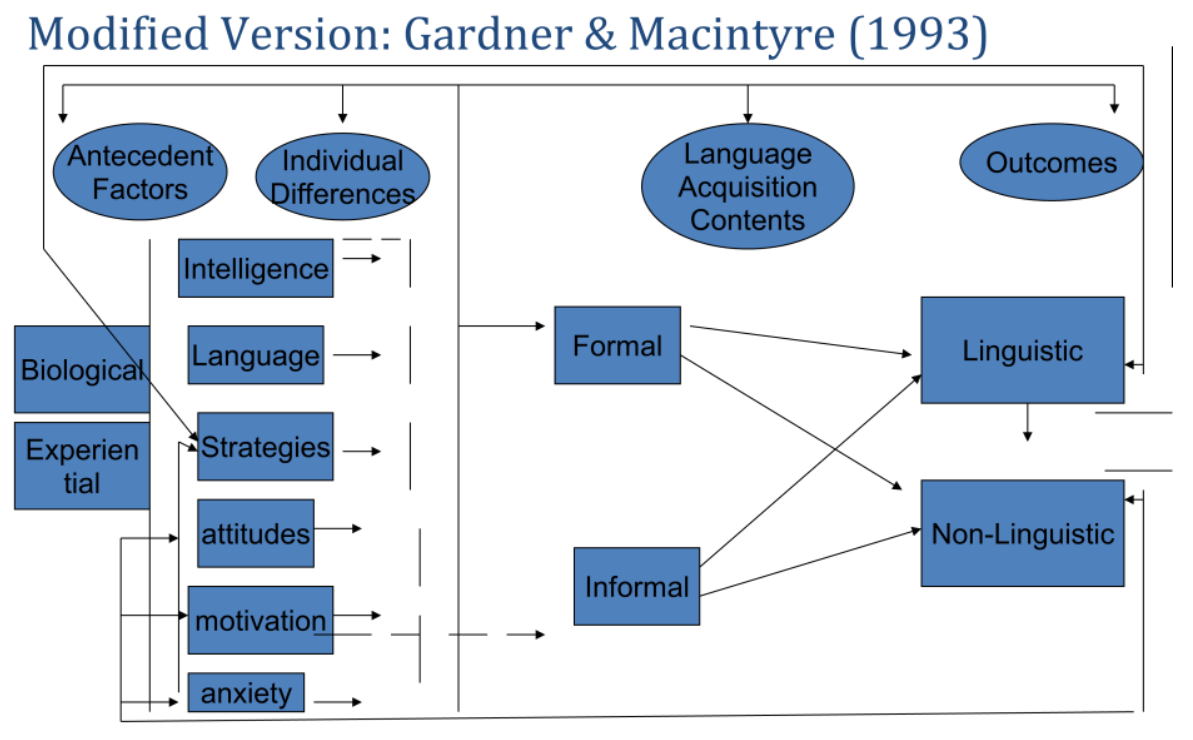

Figure 1 A:- schematic diagram showing the theoretical framework of the study(Gardner and McIntyre, 1993)

The Socio-educational Model is a modified representation of the original model of Gardner (1985). This model was taken from the Socio-Psychological Model. According to Gardner, second language must be viewed as a central social psychological phenomenon. The rationale brought about by this view refers to the school subjects that involve learning elements of the student's own cultural heritage and their acquisition of knowledge and habits that become or are already part of the makeup of the culture with which the student identifies. However, such is not the case with second languages. Second language acquisition is a process of "acquiring symbolic elements of a different ethnolinguistic community. When a learner of a second language adopts the grammar, vocabulary, pronunciation, and other structural features of the target language, then this learner is adopting the elements of another culture. The result becomes that the learner's own culture and the culture of the target language being acquired becomes an important consideration in the process.

Gardner and Macintyre's (1993) model explains L2 learning in classroom setting, in particular, the foreign language classroom. The direct and broken lines seen in the model represent different roles played by individual differences depending on the learning context. Direct lines link the cultural beliefs to four individual difference variables - 
antecedent factors (social milieu), individual differences, language acquisition contents, and outcomes - manifesting that these beliefs can influence the extent to which variables influence the second language learning achievements. Gardner and Macintyre added the categories of language attitude and strategies believing that these two have relevance to the development of language proficiency. Gardner and Macintyre believe that social values, mindset of the people and their attitude and behaviour change in the passing of times. The work of the model starts with the social milieu where learners display their initial attitude towards the culture and the target language. This social milieu influences the strategies of the learners toward acquiring a second language. As time goes on in the learning process, the learner may either appreciate or be critical to the target language. In the end, the learner gains varying outcomes (particularly positive outcomes) such as fluency and appreciation of the target culture or language.

\section{Conceptual Framework:-}

Figure 2 presents the conceptual framework of the current research. The variables of the study which are, the learner's attitude, perceptions toward Spanish, and the student's academic performance are illustrated in the schematic diagram using the IPO Model.

\begin{tabular}{|c|c|c|c|}
\hline Input & Process & Output & \\
\hline $\begin{array}{ll}\text { - } & \text { Learner's } \\
\text { attitude } \\
\text { - } \\
\text { Perceptions } \\
\text { toward } \\
\text { Spanish } \\
\text { - Academic } \\
\text { performance }\end{array}$ & $\begin{array}{l}\text { 1. Survey } \\
\text { questionnaire using } \\
\text { matched guise and } \\
\text { semantic differential } \\
\text { techniques } \\
\text { 2. Learner's final } \\
\text { grade in Spanish }\end{array}$ & & $\begin{array}{l}\text { Summary of learner's } \\
\text { attitude toward } \\
\text { Spanish as a foreign } \\
\text { language being learned } \\
\text { in the college } \\
\text { classroom }\end{array}$ \\
\hline
\end{tabular}

Figure 2 A:-schematic diagram of the conceptual framework of the study.

The variables are the data needed in the input that will be processed by means of a survey questionnaire. In the questionnaire, the modified matched guise technique was used to determine what the participants think about Spanish upon hearing the voices of one female and a male duo - one in folk song, and the other one in rap music. Also, the semantic differential technique is included in the questionnaire to determine the participants' perception upon hearing the word "Spanish" or upon hearing words and phrases in Spanish. The final outcome of the research was the summary of learner's perceptions and attitudes toward Spanish as a foreign language being learned in the college classroom.

\section{Hypothesis of the Study:-}

1. There is no significant difference among the varied perceptions of the students toward Spanish; and

2. There is no significant difference among the varied attitudes of the students toward Spanish.

Significance of the Study:-

It is important for the programs offering a foreign language to understand the language needs of the learners. Their attitudes toward learning a foreign language can be a basis for formulating an appropriate syllabus that will cater to their needs as language learners. While others think of language attitude lightly, it is actually important for people, especially language educators to consider the serious implications this problem can do to a learner. Once studied, language attitude problems can help solve the problems found unanswered inside and outside the classroom.

Time and Place of the Study:-

The study was conducted at Cavite State University for six months and most of the research was conducted inside the Language classroom of the campus.

\section{Scope and Limitations:-}

This study only discussed the language attitudes of the participants who are the 37 students enrolled in the Diploma in Hotel and Restaurant Management. The study was confined only inside one of the satellite campuses of Cavite State University. The language in question was only Spanish in which the students enrolled in the First Semester. 


\section{Methodology:-}

\section{Research Design:-}

This study employed field work where the participants were directly observed in the foreign language classroom. Then, the survey research design was used as the participants were asked to answer a questionnaire that fully described their attitudes toward Spanish.

\section{Participants:-}

Table 1 revealed that a group of 37 tertiary students (15 males and 22 females) aged 16 to 27 years old (see Table 2), belonging to a hospitality management class were observed, interviewed, and subjected to series of cognitive tests in their Spanish class.

Table 1:-Participants of the study.

\begin{tabular}{|l|l|l|}
\hline MALE & FEMALE & TOTAL \\
\hline 15 & 22 & $\mathbf{3 7}$ \\
\hline
\end{tabular}

Table 2:-Participants' age.

\begin{tabular}{|l|l|l|l|}
\hline AGE & FEMALE & MALE & TOTAL \\
\hline $16-18$ & 13 & 9 & 22 \\
$19-21$ & 5 & 5 & 10 \\
$22-24$ & 3 & 1 & 4 \\
$25-27$ & 1 & - & 1 \\
\hline & $\mathbf{2 2}$ & $\mathbf{1 5}$ & $\mathbf{3 7}$ \\
\hline
\end{tabular}

The participants were permanent residents of the Southern Tagalog Region (Region 4a). Table 3 revealed that most of them speak Tagalog, being the main language of the region, while some of these participants, while already Tagalog speakers, have parents who belong to other regions like the Ilocano (Region 1 and 2), or Hiligaynon (Regions 7 and 8) regions. Those who do not belong to the Tagalog region can speak Tagalog very well just like any typical Filipino. All the participants can also speak good English or can comprehend English well like most Filipinos do. All the participants said that they know slightly about Spanish but do not know at all how to speak the language. These students can be described as belonging to the poor to middle class group. Academically, these students opted for a two-year course rather than the four-year course because, either they have yet to decide on a four-year course or they do not like to spend longer years in school.

Table 3:-Distribution of participants' languages spoken at home.

\begin{tabular}{|l|l|}
\hline NATIVE LANGUAGE SPOKEN AT HOME & FREQUENCY \\
\hline Hiligaynon & 1 \\
Ilocano & 1 \\
Tagalog & 35 \\
\hline TOTAL & $\mathbf{3 7}$ \\
\hline
\end{tabular}

Table 4 revealed that 76 percent of the participants perceive they are "proficient" to "very proficient" in English while 70 percent claimed they were "not proficient" to "not very proficient" in Spanish.

Table 4:-Participants' perception of their proficiency in a second or foreign language.

\begin{tabular}{|l|l|l|l|l|l|}
\hline LANGUAGE & $\begin{array}{l}\text { VERY } \\
\text { PROFICIENT }\end{array}$ & PROFICIENT & $\begin{array}{l}\text { NOT } \\
\text { PROFICIENT }\end{array}$ & $\begin{array}{l}\text { NOT VERY } \\
\text { PROFICIENT }\end{array}$ & TOTAL \\
\hline English & 6 & 22 & 6 & 3 & $\mathbf{3 7}$ \\
\hline Spanish & 3 & 8 & 16 & 10 & 37 \\
\hline
\end{tabular}

In the Philippines, English is considered not a foreign language but almost like part of the Philippine languages. An average Filipino experiences listening, speaking, reading, or writing in English since childhood, which therefore makes the language almost like the Filipino's own. As Filipinos are used to hearing many languages being spoken almost everyday in many different places in the Philippines, it is not difficult for an average Filipino to like to learn a new language. For this research Table 5 revealed that 54 percent of the participants "like very much" to learn a new language while 41 percent "like much" to learn a new language. 
Table 5:-Degree of liking to learn a new language.

\begin{tabular}{|l|l|l|l|l|l|}
\hline SEX & VERY MUCH & MUCH & NOT MUCH & $\begin{array}{l}\text { NOT VERY } \\
\text { MUCH }\end{array}$ & TOTAL \\
\hline Female & 12 & 8 & 2 & - & $\mathbf{2 2}$ \\
\hline Male & 8 & 7 & - & - & $\mathbf{1 5}$ \\
\hline TOTAL & $\mathbf{2 0}$ & $\mathbf{1 5}$ & $\mathbf{2}$ & - & $\mathbf{3 7}$ \\
\hline
\end{tabular}

\section{Research Instruments:-}

The study used folk and rap songs sung by one female and a male duo, and the Second Semester 2014-2015 syllabus in Elem. Spanish which was used in the course of their study and learning of Spanish for one semester. Also, the study used the Second Semester 2014-2015 grading sheet that indicates the final grades of the participants in Elem. Spanish.

The questionnaire that was used was designed by the researcher, although the idea on some parts of this questionnaire was taken from V. B. Kashkin (2001), a linguist who carried out a language attitude study towards foreign languages in Russia.

The researcher used a questionnaire that employed the modified Match-Guise Technique and the Semantic Differential Technique - both of which are techniques used to measure a learner's attitudes and perceptions toward a language.

\section{Data Gathering Procedures:-}

The students were observed for six months during their Spanish classroom activities. Using the Second Semester 2014-2015 syllabus in Elementary Spanish, they were taught to speak and understand basic words, sentences, and phrases. They were able to have the chance to speak Spanish during classroom activities using the most common terms in Spanish. They were also encouraged to engage in small conversations. Every now and then, the teacher gave them a quiz or a long test. Finally, at the end of the semester, they were given a summative test to find out how much they have learned to understand and speak the language.

Finally, at the closing of the semester, the teacher gave each of them a questionnaire to find out their attitude toward studying and learning Spanish. The participants were asked to give their perceptions toward Spanish. They were asked to listen to two Spanish singing voices, one female and another one male, to be able to gather their attitudes toward Spanish.

\section{Data Analysis:-}

The data for the participants' perceptions toward Spanish were analyzed using a modified Matched Guise Technique when a folk song sung by a female Spanish voice and a rap song sung by a male Spanish duo were played to the participants for the first time. According to the participants, they have never heard any Spanish singers sang before this experiment. Likewise, the Semantic Differential Technique was used to find out the degree of their attitude towards the Spanish language.

The data for the academic performance of the students were determined using the following descriptions:

$1.00-1.75=$ Very Satisfactory to Outstanding

$2.00-2.75=$ Moderately Satisfactory to Satisfactory

$3.00-3.75=$ Needs Improvement

$4.00-5.00=$ Failing

\section{Statistical Treatment:-}

This research utilized the descriptive statistics - frequency, counts, and percentages - to summarize and describe the data of the study. It also utilized the inferential statistics by using Analysis of Variance (ANOVA) to determine the significant differences among the varied perceptions and attitudes of students regarding Spanish. The independent ttest was also used to determine the significant difference between the academic grades of the female participants over their male counterparts. 


\section{Results:-}

How the young adult Filipino learners perceive Spanish as a foreign language:-

Table 6 revealed the perception of the Filipino learners about the most important language for them to learn when given three choices - English, Filipino, and Spanish.

Table 6:-Most important language to learn.

\begin{tabular}{|l|l|l|l|}
\hline RANK & ENGLISH & FILIPINO & SPANISH \\
\hline (First) & 23 & 11 & 2 \\
2 (Second) & 12 & 17 & 10 \\
3 (Third) & 2 & 9 & 25 \\
\hline TOTAL & $\mathbf{3 7}$ & $\mathbf{3 7}$ & $\mathbf{3 7}$ \\
\hline
\end{tabular}

Table 7 revealed the participants' positive or negative perceptions upon hearing the name "Spanish." When they were asked, "Upon hearing the word "Spanish," what do you feel?"

Table 7:-Result of participants' perception about "Spanish".

\begin{tabular}{|l|l|l|l|l|l|l|l|l|}
\begin{tabular}{|l|l|l} 
( - ) \\
PERCEPTI \\
ON
\end{tabular} & $\begin{array}{l}\text { EXTREME } \\
\text { LY }\end{array}$ & $\begin{array}{l}\text { QUIT } \\
\text { E }\end{array}$ & $\begin{array}{l}\text { SLIGHT } \\
\text { LY }\end{array}$ & $\begin{array}{l}\text { NEUTR } \\
\text { AL }\end{array}$ & $\begin{array}{l}\text { SLIGHT } \\
\text { LY }\end{array}$ & $\begin{array}{l}\text { QUIT } \\
\text { E }\end{array}$ & $\begin{array}{l}\text { EXTREME } \\
\text { LY }\end{array}$ & $\begin{array}{l}\text { ( + ) } \\
\text { PERCEPTI } \\
\text { ON }\end{array}$ \\
\hline Bad & 3 & - & - & 6 & 13 & 10 & 5 & Good \\
Difficult & 9 & 7 & 5 & 6 & 5 & 5 & - & Easy \\
Ugly & 1 & 5 & 1 & 6 & 7 & 12 & 5 & Nice \\
Unsophistic & 2 & 2 & 1 & 7 & 11 & 12 & 2 & Glamorous \\
ated & & & & & & & & \\
Least & 3 & - & - & 4 & 14 & 11 & 5 & Best \\
Powerless & 2 & - & - & 1 & 14 & 15 & 5 & Powerful \\
Weak & 4 & 1 & 1 & 4 & 10 & 12 & 5 & Strong \\
Ineffective & 4 & 3 & - & 3 & 10 & 10 & 7 & Effective \\
Dull & 3 & 2 & 1 & 3 & 10 & 11 & 7 & Exciting \\
Unconvincing & 4 & 1 & - & 4 & 10 & 12 & 6 & Compelling \\
Passive & 2 & 4 & 1 & 1 & 13 & 11 & 5 & $\begin{array}{l}\text { Active } \\
\text { Boring }\end{array}$ \\
Lethargic & 4 & 1 & 1 & 3 & 9 & 12 & 7 & Lively \\
Unproductive & 3 & 4 & 1 & 5 & 6 & 11 & 6 & Energetic \\
Productive \\
\hline
\end{tabular}

Meanwhile, Table 8 reveals the grouped perceptions of the participants about Spanish.

Table 8:-Grouped perceptions about Spanish.

\begin{tabular}{|l|l|l|l|l|}
\hline $\begin{array}{l}(-) \\
\text { PERCEPTION }\end{array}$ & $\begin{array}{l}\text { NEGATIVE } \\
\text { RESPONSE }\end{array}$ & NEUTRAL & $\begin{array}{l}\text { POSITIVE } \\
\text { RESPONSE }\end{array}$ & $\begin{array}{l}(+) \\
\text { PERCEPTION }\end{array}$ \\
\hline Bad & $3(8 \%)$ & $6(16 \%)$ & $28(75 \%)$ & Good \\
Difficult & $21(59 \%)$ & $6(16 \%)$ & $10(27 \%)$ & Easy \\
Ugly & $7(19 \%)$ & $6(16 \%)$ & $24(65 \%)$ & Nice \\
Unsophisticated & $5(13 \%)$ & $7(19 \%)$ & $25(68 \%)$ & Glamorous \\
Least & $3(8 \%)$ & $4(11 \%)$ & $30(81 \%)$ & Best \\
Powerless & $2(5 \%)$ & $1(3 \%)$ & $34(92 \%)$ & Powerful \\
Weak & $6(16 \%)$ & $4(11 \%)$ & $27(73 \%)$ & Strong \\
Ineffective & $7(19 \%)$ & $3(8 \%)$ & $27(73 \%)$ & Effective \\
Dull & $6(16 \%)$ & $3(8 \%)$ & $28(75 \%)$ & Exciting \\
Unconvincing & $5(13 \%)$ & $4(11 \%)$ & $28(75 \%)$ & Compelling \\
Passive & $7(19 \%)$ & $1(3 \%)$ & $29(78 \%)$ & Active \\
Boring & $6(16 \%)$ & $3(8 \%)$ & $29(78 \%)$ & Lively \\
Lethargic & $9(25 \%)$ & $5(13 \%)$ & $23(62 \%)$ & Energetic \\
Unproductive & $3(8 \%)$ & $3(8 \%)$ & $31(84 \%)$ & Productive \\
Sluggish & $7(19 \%)$ & $20(54 \%)$ & Vigorous \\
\hline $\begin{array}{l}\text { df between groups }=\mathbf{2} \\
\text { df within groups }=\mathbf{4 4}\end{array}$ & \multicolumn{5}{|c|}{ F $_{\text {CRIT }}=\mathbf{3 . 2 1}(\mathbf{p}=\mathbf{0 . 0 5})$} & SS $_{\text {WITHIN }}=\mathbf{7 9 3 . 0 4 7 6}$ & MS $_{\text {BETWEEN }}=1522.73245$ \\
\hline
\end{tabular}


Computed $\mathrm{F}_{\mathrm{CRIT}}=\mathbf{8 4 . 4 9}$; this is greater than the critical value of 3.21. Therefore, The null hypothesis is rejected.

Attitudes learners have toward Spanish:-

Table 9 revealed the participants' attitudes toward Spanish through a female Spanish voice.

Table 9:-Result of participants' attitudes toward a Spanish female voice.

\begin{tabular}{|c|c|c|c|c|c|}
\hline DESCRIPTION & $\begin{array}{l}\text { Very True } \\
5\end{array}$ & $\begin{array}{l}\text { True } \\
4\end{array}$ & $\begin{array}{l}\text { Neutral } \\
3\end{array}$ & $\begin{array}{l}\text { Untrue } \\
2\end{array}$ & $\begin{array}{l}\text { Not Very } \\
\text { True } \\
1\end{array}$ \\
\hline Intelligent & 10 & 16 & 5 & 1 & 5 \\
\hline Friendly & 12 & 16 & 7 & 2 & - \\
\hline Educated & 15 & 12 & 5 & 1 & 4 \\
\hline Attractive & 10 & 11 & 10 & 5 & 1 \\
\hline Worth trusting & 8 & 13 & 13 & 3 & - \\
\hline $\begin{array}{l}\text { Having sense of } \\
\text { humor }\end{array}$ & 12 & 12 & 10 & 3 & - \\
\hline Progressive & 8 & 16 & 11 & 2 & - \\
\hline Open-minded & 16 & 13 & 7 & 1 & - \\
\hline $\begin{array}{l}\text { Having self- } \\
\text { confident }\end{array}$ & 16 & 9 & 10 & - & 2 \\
\hline $\begin{array}{l}\text { Accepting new } \\
\text { uses and customs }\end{array}$ & 8 & 14 & 13 & 2 & 0 \\
\hline Generous & 9 & 13 & 13 & 1 & 1 \\
\hline $\begin{array}{l}\text { Being able to be a } \\
\text { leader }\end{array}$ & 5 & 12 & 14 & 3 & 3 \\
\hline Funny & 7 & 7 & 12 & 8 & 3 \\
\hline Hardworking & 8 & 12 & 11 & 6 & 0 \\
\hline Proud & 18 & 8 & 6 & 2 & 3 \\
\hline Faithful & 19 & 7 & 7 & 4 & - \\
\hline Practical & 16 & 10 & 8 & 2 & 1 \\
\hline
\end{tabular}

After listening to the song, the researcher asked them to rate the voice (not the song). To further understand the result, the researcher once again grouped the descriptions into three - Positive Attitude, Neutral Attitude, and Negative Attitude. On the left side of the table, there were 17 descriptions that manifest their attitude toward the voice that they heard. Results in Table 10 revealed that majority of the answers lean toward the positive attitude. There were even a considerable number of those who answered in the neutral side than those who answered negatively.

Table 10:- Positive, neutral, and negative attitudes toward a Spanish female voice.

\begin{tabular}{|c|c|c|c|}
\hline DESCRIPTION & POSITIVE ATTITUDE & NEUTRAL & NEGATIVE ATTITUDE \\
\hline Intelligent & $26(70 \%)$ & $5(13 \%)$ & $6(16 \%)$ \\
\hline Friendly & $28(75 \%)$ & $7(19 \%)$ & $2(6 \%)$ \\
\hline Educated & $27(73 \%)$ & $5(13 \%)$ & $5(13 \%)$ \\
\hline Attractive & $21(59 \%)$ & $10(27 \%)$ & $6(16 \%)$ \\
\hline Worth trusting & $21(59 \%)$ & $13(35 \%)$ & $3(8 \%)$ \\
\hline $\begin{array}{l}\text { Having sense of } \\
\text { Humor }\end{array}$ & $24(65 \%)$ & $10(27 \%)$ & $3(8 \%)$ \\
\hline Progressive & $24(65 \%)$ & $11(30 \%)$ & $2(5 \%)$ \\
\hline Open-minded & $29(78 \%)$ & $7(19 \%)$ & $1(3 \%)$ \\
\hline $\begin{array}{l}\text { Having self- } \\
\text { confident }\end{array}$ & $25(68 \%)$ & $10(27 \%)$ & $2(5 \%)$ \\
\hline $\begin{array}{l}\text { Accepting new uses } \\
\text { and customs }\end{array}$ & $22(59 \%)$ & $13(35 \%)$ & $2(5 \%)$ \\
\hline Generous & $17(46 \%)$ & $14(38 \%)$ & $6(16 \%)$ \\
\hline $\begin{array}{l}\text { Being able to be a } \\
\text { Leader }\end{array}$ & $14(38 \%)$ & $12(32 \%)$ & $11(30 \%)$ \\
\hline
\end{tabular}




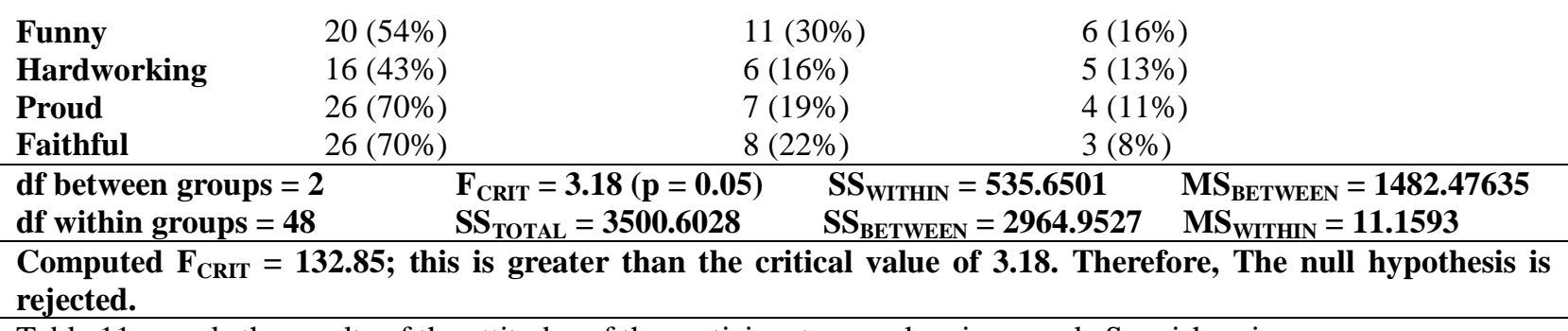

Table 11 reveals the results of the attitudes of the participants upon hearing a male Spanish voice.

Table 11:- Attitude towards Spanish male voice.

\begin{tabular}{|c|c|c|c|c|c|}
\hline DESCRIPTION & $\begin{array}{l}\text { Very True } \\
5\end{array}$ & $\begin{array}{l}\text { True } \\
4\end{array}$ & $\begin{array}{l}\text { Neutral } \\
3\end{array}$ & $\begin{array}{l}\text { Untrue } \\
2\end{array}$ & $\begin{array}{l}\text { Not Very } \\
\text { True } \\
1\end{array}$ \\
\hline Intelligent & 8 & 15 & 13 & 1 & - \\
\hline Friendly & 8 & 20 & 6 & 1 & 3 \\
\hline Educated & 9 & 11 & 15 & 1 & 1 \\
\hline Attractive & 20 & 11 & 4 & 1 & 1 \\
\hline Worth trusting & 7 & 15 & 15 & - & - \\
\hline $\begin{array}{l}\text { Having sense of } \\
\text { humor }\end{array}$ & 10 & 12 & 14 & 1 & - \\
\hline Progressive & 10 & 19 & 6 & 1 & 1 \\
\hline Open-minded & 12 & 14 & 8 & 2 & 1 \\
\hline $\begin{array}{l}\text { Having self- } \\
\text { confidence }\end{array}$ & 18 & 13 & 3 & 1 & 2 \\
\hline $\begin{array}{ll}\text { Accepting } & \text { new } \\
\text { uses } & \text { and } \\
\text { customs } & \end{array}$ & 9 & 19 & 6 & 1 & 2 \\
\hline Generous & 16 & 10 & 10 & 1 & - \\
\hline $\begin{array}{l}\text { Being able to be } \\
\text { a leader }\end{array}$ & 11 & 17 & 7 & 1 & 1 \\
\hline Funny & 13 & 12 & 9 & 3 & - \\
\hline Hardworking & 16 & 12 & 8 & 1 & - \\
\hline Proud & 20 & 13 & 3 & 1 & - \\
\hline Faithful & 14 & 16 & 6 & 1 & - \\
\hline Practical & 8 & 17 & 8 & 2 & 2 \\
\hline
\end{tabular}

Table 12 revealed the results of the study when indicating the respondents' impression of the male Spanish voice.

Table 12:-Positive, neutral, and negative attitudes toward a Spanish male voice

\begin{tabular}{|c|c|c|c|c|}
\hline DESCRIPTION & POSITIVE ATTITUDE & NEUTRAL & \multicolumn{2}{|l|}{ NEGATIVE ATTITUDE } \\
\hline Intelligent & $23(62 \%)$ & $13(35 \%)$ & $1(3 \%)$ & \\
\hline Friendly & $28(75 \%)$ & $6(16 \%)$ & $4(11 \%)$ & \\
\hline Educated & $20(54 \%)$ & $15(41 \%)$ & $2(6 \%)$ & \\
\hline Attractive & $31(84 \%)$ & $4(11 \%)$ & $2(6 \%)$ & \\
\hline Worth trusting & $22(59 \%)$ & $15(41 \%)$ & $(0 \%)$ & - \\
\hline $\begin{array}{l}\text { Having sense of } \\
\text { humor }\end{array}$ & $22(59 \%)$ & $14(38 \%)$ & $1(3 \%)$ & \\
\hline Progressive & $29(78 \%)$ & $6(16 \%)$ & $2(6 \%)$ & \\
\hline Open-minded & $26(70 \%)$ & $8(22 \%)$ & $3(8 \%)$ & \\
\hline $\begin{array}{ll}\text { Having } & \text { self- } \\
\text { confidence } & \end{array}$ & $31(84 \%)$ & $3(8 \%)$ & $3(8 \%)$ & \\
\hline $\begin{array}{l}\text { Accepting new uses } \\
\text { and customs }\end{array}$ & $28(75 \%)$ & $6(16 \%)$ & $3(8 \%)$ & \\
\hline Generous & $26(70 \%)$ & $10(27 \%)$ & $1(3 \%)$ & \\
\hline $\begin{array}{l}\text { Being able to be a } \\
\text { leader }\end{array}$ & $28(75 \%)$ & $7(19 \%)$ & $2(6 \%)$ & \\
\hline
\end{tabular}




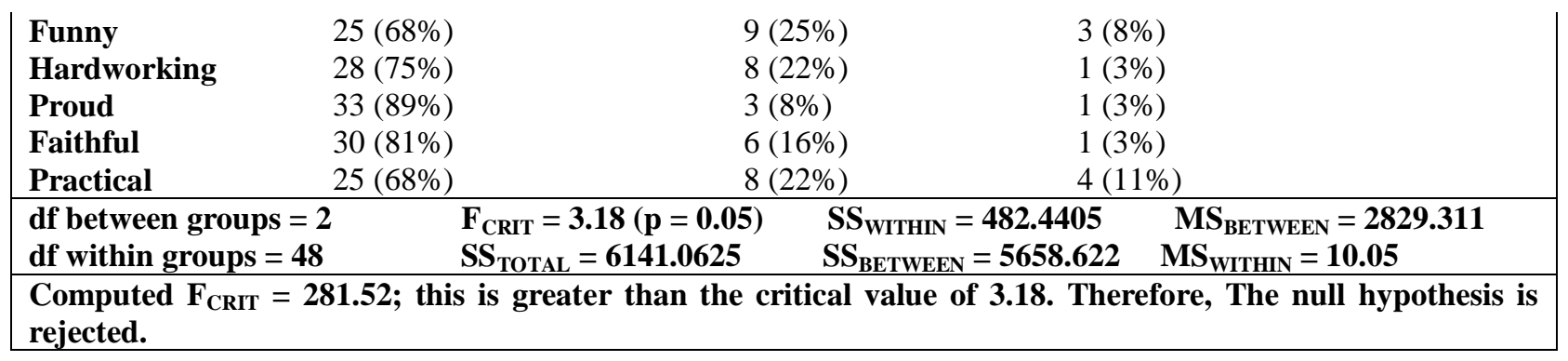

Academic performance of the participants:-

Table 13 reveals the final grades of students in their Spanish course.

Table 13:-Final grade of participants in Spanish.

\begin{tabular}{|c|c|c|c|}
\hline $\begin{array}{l}\text { FEMALE } \\
\text { PARTICIPANT }\end{array}$ & $\begin{array}{l}\text { ACADEMIC } \\
\text { PERFORMANCE }\end{array}$ & MALE PARTICIPANT & $\begin{array}{l}\text { ACADEMIC } \\
\text { PERFORMANCE }\end{array}$ \\
\hline 1 & 2.75 & 1 & 2.50 \\
\hline 2 & 3.00 & 2 & 2.75 \\
\hline 3 & 2.50 & 3 & 2.50 \\
\hline 4 & 3.00 & 4 & 3.00 \\
\hline 5 & 2.50 & 5 & 3.00 \\
\hline 6 & 2.50 & 6 & 3.00 \\
\hline 7 & 3.00 & 7 & 2.50 \\
\hline 8 & 2.25 & 8 & 3.00 \\
\hline 9 & 2.50 & 9 & 2.50 \\
\hline 10 & 3.00 & 10 & 2.50 \\
\hline 11 & 2.50 & 11 & 2.00 \\
\hline 12 & 2.50 & 12 & 2.75 \\
\hline 13 & 3.00 & 13 & 3.00 \\
\hline 14 & 2.25 & 14 & 2.75 \\
\hline 15 & 2.25 & 15 & 2.75 \\
\hline 16 & 2.75 & & \\
\hline 17 & 2.25 & & \\
\hline 18 & 3.00 & & \\
\hline 19 & 3.00 & & \\
\hline 20 & 2.75 & & \\
\hline 21 & 3.00 & & \\
\hline 22 & 3.00 & & \\
\hline TOTAL $=22$ & $\begin{array}{l}n_{1}=22 ; x_{1}=2.69 \\
S D=0.29\end{array}$ & TOTAL $=15$ & $\begin{array}{l}n_{2}=15 ; x_{2}=2.70 \\
S D=0.28\end{array}$ \\
\hline
\end{tabular}

Significant difference among the varied perceptions of the students toward Spanish:-

Referring to Table 8 of this study, the researcher measured the perceptions of the students toward Spanish to find out if the hypothesis posed in this study which states that "There is no significant difference among the varied perceptions of the students toward Spanish" is true. This research utilized the one-way ANOVA to answer the critical question regarding the participants' perceptions. The positive, negative, and neutral descriptions were grouped and calculated and were tabulated. After determining the degrees of freedom of between (2) and within (42) groups, the $\mathrm{df}_{\mathrm{TOTAL}}$ was calculated at 44 and the $\mathrm{F}_{\mathrm{CRIT}}=3.21$ where $\mathrm{p}=0.05$. Then, the sums of squares were analyzed. After obtaining the results and using the critical value of the $\mathrm{F}$ test at 3.21 with 0.05 level of significance $(\mathrm{p}=.05)$, the calculated $\mathrm{F}_{\mathrm{CRIT}}=84.49$ which is greater than the critical value of 3.21 . Therefore, the statement that says there is no significant difference among the varied perceptions of the students toward Spanish is rejected. The alternative hypothesis is thus accepted. This means that the participants had varying degrees of perceptions toward 
Spanish. These perceptions were clearly manifested when they were subjected to Osgood's Semantic Differential Technique.

\section{Significant difference among the varied attitudes of the students toward Spanish:-}

Referring to Table 10 where the learners were asked to listen to a female voice, it was initially hypothesized that there is no significant difference in the attitude of the participants toward Spanish upon listening to the voice of a female singing De Colores. Through the one way ANOVA, the inferential statistics of the data were calculated and analyzed. The positive, negative, and neutral descriptions were grouped and calculated and were tabulated. After determining the degrees of freedom of between (2) and within (48) groups, the $\mathrm{df}_{\mathrm{TOTAL}}$ was calculated at 50 and the $\mathrm{F}_{\mathrm{CRIT}}=3.18$ where $\mathrm{p}=0.05$. Then, the sums of squares were analyzed. After obtaining the results and using the critical value of the $\mathrm{F}$ test, the calculated $\mathrm{F}_{\mathrm{CRIT}}=132.85$ which is greater than the critical value of 3.18 . Therefore, the statement that says there is no significant difference among the varied perceptions of the students toward Spanish is rejected. The alternative hypothesis is thus accepted. This means that the participants had varying degrees of perceptions toward Spanish. These perceptions were clearly manifested when they were subjected to the modified Matched Guise Technique.

Meanwhile, in Table 12 where the learners were asked to listen to a male voice, it was initially hypothesized that there is no significant difference in the attitude of the participants toward Spanish upon listening to the voice of a male singing the rap song YoteEsperare. Through the one way ANOVA, the inferential statistics of the data were calculated and analyzed. The positive, negative, and neutral descriptions were grouped and calculated and were tabulated. After determining the degrees of freedom of between (2) and within (48) groups, the $\mathrm{df}_{\mathrm{TOTAL}}$ was calculated at 50 and the $\mathrm{F}_{\text {CRIT }}=3.18$ where $\mathrm{p}=0.05$. Then, the sums of squares were analyzed. After obtaining the results and using the critical value of the $F$ test, the calculated $F_{\text {CRIT }}=281.52$ which is greater than the critical value of 3.18. Therefore, the statement that says there is no significant difference among the varied perceptions of the students toward Spanish is rejected. The alternative hypothesis is thus accepted. This means that the participants had varying degrees of perceptions toward Spanish. These perceptions were clearly manifested when they were subjected to the modified Matched Guise Technique.

\section{Discussion:-}

\section{Analysis of results:-}

When the respondents were asked to rank the most important language they must learn, 62 percent asserted English as the most important among the three languages. The second most important language according to them is Filipino, their native language. Finally, 68 percent of the participants mentioned Spanish as their third or last choice. The reason for the result is that in the Philippines, English is always considered a language used in education, business and trade. Another reason is that English as a language is always connected to the Filipinos' desire to go abroad to work; hence, the utilitarian purpose of this language to them. An article in one of the Philippines' leading newspaper, The Philippine Star, mentioned how Filipinos value English in the same way that they value their native tongue which is Pilipino (based on Tagalog). The article also mentioned how Filipinos take pride in leading their Asian neighbors when it comes to speaking English (As a Matter of Fact, De Guzman, April 30, 2007 issue).

Through a questionnaire, the respondents were also asked to answer the question "What do you think can learning the Spanish language do to you as a learner of another language? Majority (92\%) of the participants answered that Spanish "will be useful when I go abroad." Likewise, most of them (86\%) perceive that Spanish will "help me in the program I am presently taking." The third best answer was "It will make me useful" (73\%). Surprisingly, there were those who answered that Spanish can "make me popular to my friends" and "It will give me an edge over others who do not know foreign languages" (51\%). The respondents' answer of using Spanish to go abroad goes with the attitude they also have about English as a utilitarian language that they can use when they land a job in Spanishspeaking countries. The best answers of the participants confirmed the assertion of Randhawa and Korpan (1973) about the utilitarian predisposition of a language which talks about the usefulness of a new language to a learner. Likewise, Gardner and Lambert's (1959) study revealed a similar reason regarding English as an instrument of a learner who wants to go abroad. Over all, it can be summed up out of these answers from the participants that Spanish can be a useful language which they perceive will help them answer their need for communication as they get employed abroad.

In using Osgood's Semantic Differential Technique, the participants were asked to check the box having negatives $3,2,1,0$ for neutrality, and positive 1,2, and 3 rating. They were also told to be mindful of the bipolar descriptions 
given regarding Spanish with their corresponding negative, neutral, or positive ratings. The negative descriptions are placed on the left side of the table while the positive descriptions are on the right place. The neutral part is placed in the center of the table. The result of this technique gave very interesting remarks from the participants about their positive or negative perception of Spanish. To further understand the results, the researcher grouped the answers into three descriptions - Negative Response, Neutral, and Positive Response. As can be seen in Table 8, 21 percent of the participants negatively perceived Spanish as "difficult." Positively however, the participants think highly of the Spanish language as "powerful" (92\%), "productive" (84\%), "best" (81\%), "lively" and "active" (78\%). The respondents' response of difficult is acceptable as students always perceive new knowledge as initially difficult to learn. The positive answer of "powerful" could perhaps be equated to the 333 years of Spanish colonization in the Philippines. As this is an integral part of the country's history, the respondents most probably think of the Spanish language as synonymous to the authoritarian rule that their ancestors experienced in the hands of the Spanish conquistadores.

Osgood (1957) explained that the semantic differential technique reveals the three dimensions a person has about attitude. These are Evaluation, Potency, and Activity. Evaluation is concerned with whether a person thinks positively or negatively about the attitude topic (Example, dirty-clean ugly-beautiful). Meanwhile, the dimension of Potency is concerned with how powerful the topic is for the person (Example, cruel-kind, weak-strong). Finally, Activity refers to the topic as being active or passive. In the present research, the first five pairs of perceptions refer to Evaluation, while the second five pairs refer to Potency, and the last five pairs refer to Activity. Analyzing the perceptions of the participants, their evaluation of Spanish yielded positive perceptions of "Best" being the top answer (81\%), followed by "Good" (75\%), "Glamorous" $(68 \%)$ and "Nice" $(65 \%)$. The only remarkable negative perception was "Difficult" at 59 percent. This is not a surprise at all knowing that Spanish is a foreign language to the Filipinos although Spanish words are embedded in the Philippine language. In fact, one example is the days of the week where the Spanish terms are exactly the same as the Filipinos would refer to them (Monday - Lunes, Tuesday - Martes etc.) However, majority of the Spanish words that these learners learned in the classroom are definitely foreign to them; hence, they perceive the Spanish language as difficult.

The researcher asked the participants to listen to the Spanish folk song "De Colores," being sung by a female Spanish singer. This song is popular to devout Catholics in the Philippines who join the cursillo which is a religious organization of repentant members who want to lead a good life as they leave their "sinful" past. The participants being part of the so-called "millennials" do not anymore know what the song is and who the singer was and the encounter with a folk song was their first time to listen to a Spanish song. The result revealed that the participants' impressions of the Spanish language are mostly "educated," "intelligent," "friendly" and "progressive." The crisp and snappy female voice gave the respondents these impressions, perhaps because they associate the Spanish language to their impression of knowledge acquired in the school as being difficult but providing learning that makes them progressive individuals. When asked to categorize their attitude as positive, neutral, and negative toward a Spanish female voice, the equivalent percentage found in Table 10 shows that the top answer of the participants regarding a female Spanish voice is the description "open-minded" (78\%). Other top answers include "friendly" (75\%), "educated" (73\%), "faithful" (70\%), "practical" (70\%), and "intelligent" (70\%). The lowest answer given by the participants belonged to the adjective "funny" (35\%). The negative answers are not as remarkable as the positive or the neutral answers of the participants. This is an indication of the best feelings the participants have toward Spanish.

On the other hand, the researcher played the rap song Yoteesperare (2012) which became a number one song in Spain. The song is a love song but possessing a strong touch of modern rap music that is considered standard in the present time. The participants are used to listening to American and British pop and rap genres, including the Filipino rap music. For this reason, this is their first time to listen to a Spanish rap with artists that are unknown to them. However, considering the fact that the genre of the music being played is not new to them, it was revealed in the study that upon hearing the male voice, the participants" answers yielded positive descriptions of "proud" (89\%), "having self-confident" (84\%), "attractive" (84\%), and "faithful" (81\%). Other answers include "progressive" (78\%), "accepting new uses and customs" (76\%), "being able to be a leader" (76\%), "hardworking" (76\%), and "friendly" $(76 \%)$. The adjective "proud" in this case means being "full of pride." When they were asked why this impression, they said that they can feel the male voice's satisfaction as he unleashes the words that he utter during the rap performance. They said they also noticed how comfortable the male voice was in delivering the message of the song. It can also be seen that like their attitude toward a female voice, the participants' negative answers were unremarkable. The neutral answers were more worth noting than the negative ones. In contrast to their attitude 
toward a female voice of being "educated," that is actually one of the top answers of the participants, this description is the lowest $(54 \%)$ in the male category.

Meanwhile, about how they learned Spanish in the class, it shows that the female participants obtained a mean grade of 2.69 while the male participants obtained a mean grade of 2.70 . These two averages show no dominance over any one of the participants, which means that their range of academic performance is equal if not the same in their degree of learning a foreign language in the classroom.

In the commencement of their Spanish training four months before this research, when these participants entered the foreign language classroom for the first time, they did not know anything about Spanish. However, the first time that they learned the Spanish alphabet, they were glad to know that the sounds are very similar to the Filipino language. For this reason, their early judgment of the Spanish language was "easy" and "tolerable."

However, in the 18 sessions ( 3 hours per week) that they attended, they realized the "difficulty" of the course. Particularly, when they were reciting "Padre Nuestro," the Lord's Prayer in Spanish, they found it "too taxing" and "very rigorous."

In the theory of second language acquisition, Saxton's (2010) table of linguistic milestones indicate that learners age 18 may already understand around 50 new foreign words and the learners can already produce two-word utterances. Also, at 24, they may produce multi-word utterances produced with basic grammatical features.

One factor that contributes to the difficulty of the participants in learning Spanish is the absence of linguistic environment where the learners are supposed to obtain input and interaction with the first language speakers. And while their range of academic performance looks the same, it should not be forgotten here that language learners have individual differences that make them find language study whether easy or difficult. Their motivation, aptitude, and learning strategies all contribute to their success in learning a new language. Hence, because they are studying Spanish outside the linguistic environment, they have no L1 authorities to rely on, What more, even their foreign language instructor is not a L1 speaker of the target language.

The study of Kong et al. (2012) studied the relationship of academic performance to language learning. Their research showed that studying a language (like English) is an important predictor in determining the academic performance of a learner.

In the present research, inferential statistics using independent $t$-test for students' academic performance was used to statistically determine if there is or there is no significant difference between the academic grades of the female participants and the male participants. After determining the degrees of freedom $\left(\mathrm{n}_{1}=21 ; \mathrm{n}_{2}=14\right)$ and obtaining the grand degrees of freedom $\left(\mathrm{n}_{1}+\mathrm{n}_{2}=35\right)$, the critical value of 1.6896 was obtained at .05 level of significance. Calculating the mean scores $\left(\mathrm{x}_{1}=2.69 ; \mathrm{x}_{2}=2.70\right)$ and obtaining the standard deviation $\left(\mathrm{x}_{1}=0.29 ; \mathrm{x}_{2}=0.28\right)$, the $t$ was calculated where the computed value of -0.128 was obtained. In the end, the computed value is below the critical value, which means that there is no significant difference between the academic grades of the female and that of the male participants.

In the present research, this result means that both the female and male participants dealt with Spanish in the same level of understanding. This also means that academically, the participants have the same degree of academic excellence toward studying a foreign language.

\section{Conclusion:-}

The following conclusions were therefore made based on the objectives of the study:

1. That the young adult Filipinos generally perceive Spanish positively. They are also keener on discovering the language, as seen in the neutral scores given. However, the degree of negativity toward the Spanish language is not remarkable.

2. That the attitude of the young adult Filipinos toward Spanish can be described as generally positive. There is a big tendency for the learners to tolerate the language more than reject learning it as seen in the results of the neutral and negative scores.

3. That after a semester of learning Spanish, the participants' academic scores revealed a Moderately Satisfactory to Satisfactory result. In utilizing the t-test, it was found out that there is no significant difference between the 
academic scores of the female participants and the male participants. This means both the female and male participants dealt with Spanish in the same level of understanding. This also means that academically, the participants have the same degree of academic excellence toward studying a foreign language.

4. That there is a significant difference on the varied perceptions of the participants about Spanish. The findings is attested by the ANOVA scores which show the varying perceptions of the participants toward Spanish like being "powerful" (92\%), "productive" (84\%), "best" (81\%), "lively" and "active" (78\%) which are all in the positive. Also, there is the overall negative feeling of the language being "difficult."

5. That there is a significant difference on the varied attitudes of the participants toward Spanish. Through the ANOVA, the participants generally assessed the female Spanish voice as "open-minded" (78\%). Other top answers include "friendly" (75\%), "educated" (73\%), "faithful" (70\%), "practical" (70\%), and "intelligent" (70\%). The lowest answer given by the participants belonged to the adjective "funny" (35\%). Meanwhile, the male Spanish voice was assessed as being positively "proud" (89\%), "having self-confident" (84\%), "attractive" $(84 \%)$, and "faithful" (81\%). Other answers include "progressive" (78\%), "accepting new uses and customs" (76\%), "being able to be a leader" (76\%), "hardworking" (76\%), and "friendly" $(76 \%)$.

\section{Recommendations:-}

Based on the objectives of the present study, the following recommendations are set forth about the perceptions and attitudes of young adult Filipinos toward Spanish:

1. Since the young adult Filipinos perceive Spanish in the positive, the language teacher must design a syllabus that will inspire the learners to pursue studying Spanish. This syllabus must be communication-centered and task-based and must help the learners to learn and not study, Spanish.

2. Since the attitude of the young adult Filipinos toward Spanish is positive, the language teacher may go an extra mile by introducing the learners to the cultures and traditions of Spanish-speaking countries, and perhaps, compare these with the culture and traditions found in the Philippines which are similar to the Spanish culture. The language teacher may also encourage the learners to use the social media to befriend people who speak Spanish so that they can have the chance to use the language through first-hand experience.

3. With a tolerable academic grade, the learners can be able to acquire Spanish and with constant use, they can add this language up to their list of second languages like English.

4. Since Spanish is generally perceived as a powerful language, the language teacher must take this opportunity to emphasize Spanish as a language that is needed internationally. Since the participants look at this language as utilitarian or one that can help them get through a Spanish-speaking country to find a target job, the language teacher must continue to encourage the learners to consider seriously Spanish by learning the language constantly. Likewise, the university may add Intermediate Spanish or Advanced Spanish courses that will help enhance the knowledge of the students in this language.

5. The participants' varied positive attitudes toward Spanish can be helpful in inspiring the students to look for a job in Spanish-speaking countries where they can appreciate Spanish more and also, appreciate the people and their culture.

\section{References:-}

1. Ang, G. R. (1978). The Filipino as a bilingual or multilingual: Some implications. Philippine Quarterly of Culture and Society, Vol 6 No. 3 September 1978, pp. 187-189.

2. Borlongan, A. M. (2009). A survey on the language use, attitudes, and identity in relation to Philippine English among young generation Filipinos: an initial sample from a private university. Philippine ESL Journal, Vol. 3, August 2009, pp. 74-107.

3. Brown, H. D. (1994). Principles of Language Learning and Teaching (Third Edition). Prentice Hall Regents, Prentice Hall, Inc.

4. De Guzman, S. S. (2007). Do you realize the importance of English in the world today?, As a Matter of Fact. Retrieved at www.philstar.com on April 29, 2015 (Available).

5. Doughty, C.; Williams, J., eds. (1998). Focus on form in classroom second language acquisition. Cambridge: Cambridge University Press.

6. Eagly, A. H., \& Chaiken, S. (2005). Attitude research in the 21st century: The current state of knowledge. Mah wah, NJ, US: Lawrence Erlbaum Associates Publishers.

7. Ellis, R. (1994). The study of second language acquisition. Oxford Oxfordshire: Oxford University Press.

8. Fasold, R. (1984) The sociolinguistics of society. Oxford, Blackwell. 
9. Gardner, R. C. and Lambert, W. E. (1972). Attitudes and motivation in language study. Rowley, MA: Newbury House Publishers.

10. Gardner, R. C. (1985). Social psychology and second language learning: The role of attitudes and motivation. Edward Arnolds, London.

11. Gardner, R. C. and Smythe, P. C. (1975a). Motivation and Second Language Acquisition. The Canadian Modern Language Review 31, 218-30.

12. Kong, J., Powers, S., Starr, L., and Williams, N. (2010). Connecting English language learning and academic performance: a prediction study. American Educational Research Association. British Columbia, Canada.

13. Melander, L. (2003). Language attitudes: Evaluational reactions to spoken language.

14. Obiols, M. S. (2002). The Matched Guise Technique: A critical approximation to a classic test for formal measurement of language attitudes. Retrieved March 25, 2015 at http://www.cultura.gencat.net/llengcat.noves.

15. Randhawa, B. S. and Korpan, S. M. (1973). Assessment of some significant affective variables and the prediction of achievement in French. Canadian Journal of Behavioural Science 5, 24-33.

16. Ryan, E. B.; Giles, H. (1982). Attitudes towards language variations. Edward Arnolds, London. 